\title{
Freshwater diatom communities from Ile Amsterdam (TAAF, southern Indian Ocean)
}

\author{
Barbora Chattová ${ }^{1}$, Marc Lebouvier ${ }^{2} \&$ Bart Van De ViJver ${ }^{3,4}$
}

\author{
${ }^{1}$ Department of Botany \& Zoology, Faculty of Science, Masaryk University, Kotlarska 2, 61137 Brno, Czech \\ Republic \\ ${ }^{2}$ UMR 6553 Ecobio CNRS, Université de Rennes 1, Station Biologique, F-35380 Paimpont, France \\ ${ }^{3}$ Botanic Garden Meise, Department of Bryophyta and Thallophyta, Domein van Bouchout, B-1860 Meise, \\ Belgium; Corresponding author e-mail:vandevijver@br.fgov.be \\ ${ }^{4}$ University of Antwerp, Department of Biology, ECOBE, Universiteitsplein 1, B-2610Wilrijk, Belgium
}

\begin{abstract}
Diatom and water chemistry samples were collected during the austral summer of 2007 from lakes, streams and bogponds on Ile Amsterdam (TAAF), a small island located in the southern Indian Ocean. A diverse diatom flora of 104 taxa was found, dominated by several Pinnularia taxa, Frustulia lebouvieri, Kobayasiella subantarctica, Eunotia paludosa, E. muscicola and Planothidium subantarcticum. Biogeographically, the Ile Amsterdam freshwater diatom flora is composed of cosmopolitan, sub-Antarctic and endemic elements. The biogeographical analysis showed that almost $17 \%$ of all observed taxa can be considered endemic to Ile Amsterdam with an additional 14\% showing an exclusive sub-Antarctic distribution. The flora can be considered as typical for oceanic islands based on its disharmonic composition with several genera lacking and other being overrepresented.

Canonical Component Analysis was used to classify the samples based on their chemical characteristics, revealing that, specific conductance, sulphate and $\mathrm{pH}$ were the main factors dividing the samples into four different groups. The geological history of the island in combination with the climate and the specific environmental features of the main habitat in the Caldera most likely shaped the composition of the actual diatom communities.
\end{abstract}

Key words: Bacillariophyta, biogeography, ecology, Ile Amsterdam, southern Indian Ocean, sub-Antarctic region

\section{INTRODUCTION}

Diatoms (Bacillariophyceae) are one of the most abundant and species-rich algal groups in freshwater and terrestrial ecosystems in the (sub-)Antarctic region (Jones 1996; VAN DE VIJVER \& BeYens 1999a; SABBE et al. 2003). The past few years, there has been an increasing effort in revising the freshwater and limno-terrestrial diatom flora of the entire (sub-) Antarctic region. Especially the diatom flora on the islands in the southern Indian Ocean has been the subject of intensive taxonomic studies (a.o. RoMERo \& VAN De ViJVer 2011; VAN de ViJver et al. 2002a, 2002b, 2011, 2013; WiтKOWSKI et al. 2012) followed by detailed ecological surveys of the diatom communities inhabiting these islands [e.g., Iles Kerguelen (VAN DE VIJVER et al. 2001); Iles Crozet (VAN DE ViJVER \& Beyens 1999b; Van de ViJver et al. 2002a), Heard Island (VAN DE VIJVER et al. 2004a) and the Prince Edward Islands (VAN De VIJVER et al. 2008a)].

The results of these studies clearly indicated the presence of a highly specific diatom flora on all investigated islands containing a large number of species with a very restricted, even sometimes endemic distribution, contrary to the generally accepted ideas about the cosmopolitan nature of micro-organisms worldwide (Finlay \& ClaRKe 1999).

Just north of the sub-Antarctic islands in the southern Indian Ocean, two small volcanic islands can be found, Ile Amsterdam $\left(77^{\circ} 30^{\prime} \mathrm{E}, 37^{\circ} 50^{\prime} \mathrm{S}\right)$ and Ile Saint Paul $\left(77^{\circ} 31^{\prime} \mathrm{E}, 38^{\circ} 41^{\prime} \mathrm{S}\right)$. The first results of a survey on the terrestrial and freshwater diatoms of Ile Amsterdam have been published in 1999 (VAN DE VIJVER \& BEYENS 1999c) reporting 90 taxa from 24 samples. Based on these results, two sampling campaigns have been undertaken in 1999 and 2007 in order to investigate in-depth the diatom flora of both islands. A new Luticola species was published based on material collected in 1999 from Ile Saint Paul (VAN DE ViJver et al. 2002b). In 2008, a paper describing three Eunotia EHRENBERG species was published (VAN DE ViJVER et al. 2008b) followed by the description of a new genus, Microfissurata Lange-Bertalot, CANTONATI et VAN DE VIJVER, based on two species of which one was found on Ile Amsterdam (i.e. Microfissurata australis VAN 
DE Vijver et Lange-Bertalot; Cantonati et al. 2009). Several years later, 23 different Pinnularia EHRENBERG taxa have been observed during a taxonomic analysis of aquatic, moss and soil samples, of which twelve did not correspond to any other currently known species and were described as new species (VAN DE VIJVER et al. 2012). Special attention was further given to the different lava tube diatom communities that are present on the island. As a result of this, several unknown taxa were found and described as new for science (VAN DE ViJver \& Cox 2013; Lowe et al. 2013). Despite this growing interest and the handful of taxonomic papers, little is known on the ecology and composition of the diatom communities of Ile Amsterdam.

The present paper focusses on the ecological preferences of the freshwater diatom flora of Ile Amsterdam, its biogeographical position within the southern Indian Ocean Province, and the different diatom communities on the island in relation to several habitat characteristics.

\section{Material ANd Methods}

Study Site. Ile Amsterdam is an entirely volcanic island located in the southern Indian Ocean, halfway between the African continent and Australia (Fig. 1) and is one of the most remote and isolated oceanic islands in the world. The island, with a total surface of $55 \mathrm{~km}^{2}$, presents the shape of a small cone culminating at $881 \mathrm{~m}$ (Mont de la Dives) and is geologically spoken, very young, with its main part arisen during the period 400-200 kyr BP (GIRET 1987, DouceT 2003). Ile Amsterdam has a temperate oceanic climate with a mean annual temperature of $14.0^{\circ} \mathrm{C}$ with minimum and maximum temperatures of $11.2{ }^{\circ} \mathrm{C}$ in August and $17.4{ }^{\circ} \mathrm{C}$ in February respectively (LeBouvier \& Frenot 2007). Strong westerly winds are frequent, especially in winter. Relative humidity is generally high $(>80 \%)$ due to the frequency of low cloud ceilings. Precipitation, falling primarily as rain, is usually high with an annual average of $1114 \mathrm{~mm}$ distributed over more than 220 days at the meteorological station (Martin de Viviès, $27 \mathrm{~m}$ a. s. 1.); a dry period occurs in summer (c. $70 \mathrm{~mm}$ in February). According to a one year record (FRENOT \& VAlleix 1990) in the Caldera at $700 \mathrm{~m}$ a.s.l. the mean temperature is lower by $7^{\circ} \mathrm{C}$ while the precipitation is almost twice as high.

Permanent waterbodies are restricted to the higher plateau (Caldera, Plateau des Tourbières) in the centre and the west-southwestern part of the island (Falaises d'Entrecasteaux, Grandes Ravines). Almost all other areas lack (semi-permanent) waterbodies due to the steepness of the slope and the permeability of the lava tunnels, holes and fissures. Due to frequent fog and clouds, and high relative humidity in the upper areas (from $500 \mathrm{~m}$ a.s.1.), extensive peat formations have been developed, especially in the volcanic caldera (HEGER et al. 2009).

Ile Amsterdam is not truly sub-Antarctic. Nevertheless, on the higher central plateau, the vegetation has a typical sub-Antarctic character consisting of mosses, small ferns [e.g., Blechnum penna-marina (POIRET) KUHN], grasses, sedges (e.g., Uncinia brevicaulis THOUARS) and Lycopodium ssp. (TREHEN et al. 1990). The rather species-poor vegetation

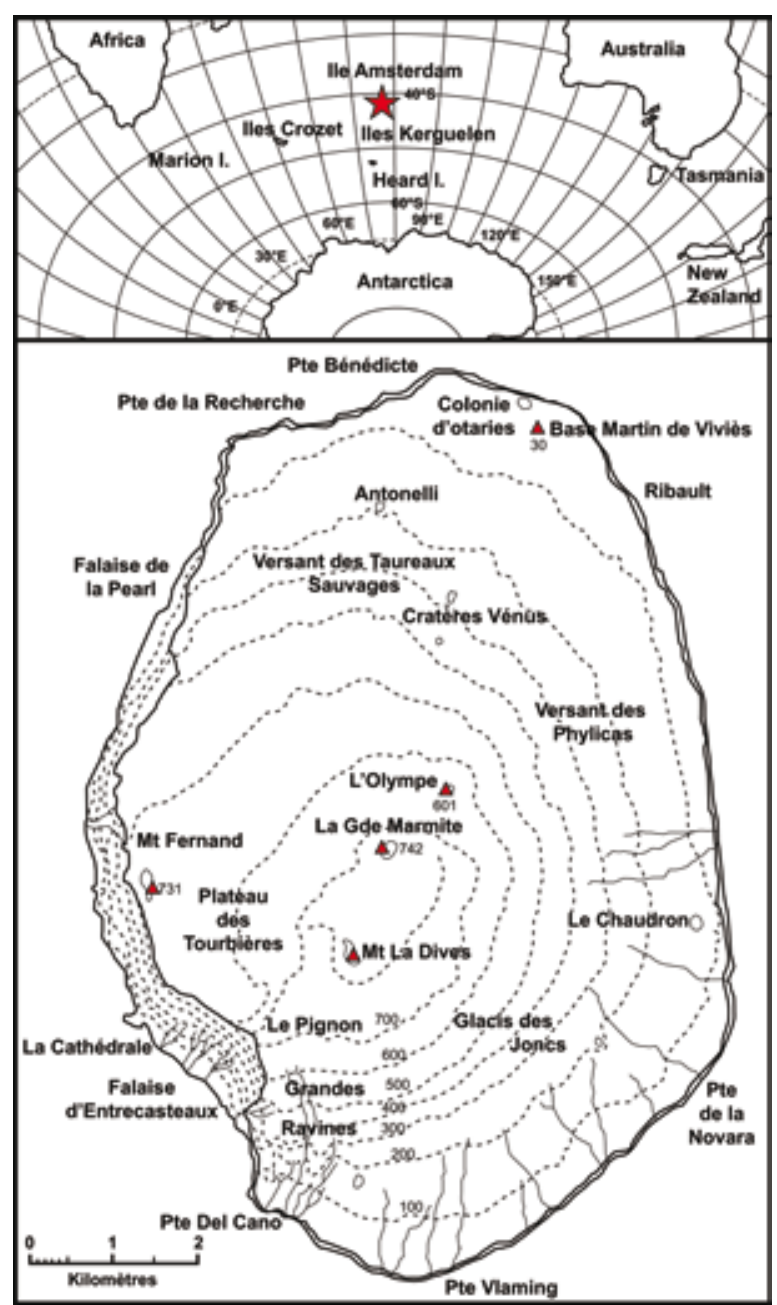

Fig. 1. (a) Location of Ile Amsterdam in the southern hemisphere; (b) Ile Amsterdam with the main topographic indications used in the text.

is dominated by both native (43) and introduced (56) species, reflecting the isolation of the island (FRENOT et al. 2001). The vegetation differs however in two aspects from the other islands in the southern Indian Ocean. The lower part of the island used to be covered by dense Phylica arborea THOUARs forests, a native tree restricted to the Tristan da Cunha archipelago and Ile Amsterdam, patches of which are still present on the island. Secondly, the native flora includes also several (endemic) Sphagnum species, forming extensive peatlands above $500 \mathrm{~m}$ a.s.l. However, Sphagnum peatlands are absent on the other sub-Antarctic islands (FLATBERG et al. 2011). Although the diversity of the lichen flora is rather poor (77 species), recently a new lichen species, Caloplaca amsterdamensis Aptroot et ERTZ was described (APTROOT et al. 2011).

The endemic fauna is composed of a few marine bird species such as the rare Amsterdam albatross (Diomedea amsterdamensis Roux et al.) and several large fur seal colonies (Arctocephalus tropicalis GrAY). Fires, past human activities and the introduction of cattle (Bos taurus Linnaeus) have caused serious ecological damage and altered significantly the biodiversity of the island (Micol \& JouvENTIN 1995) although it is unclear what the effects are on the micro-flora and -fauna of the island. 
Table 1. Physico-chemical characteristics (when available) of samples collected on Ile Amsterdam, temperature in ${ }^{\circ} \mathrm{C}$, conductivity in $\mu \mathrm{S} . \mathrm{cm}^{-1}$, altitude in m.a.s.l., other variables in mg..$^{-1}$

\begin{tabular}{|c|c|c|c|c|c|c|c|c|c|c|c|c|c|}
\hline sample & $\begin{array}{l}\mathrm{NO}^{2-} \\
+\mathrm{N}^{3-}\end{array}$ & $\mathrm{NH}_{4}^{+}$ & $\mathrm{PO}_{4}^{3-}$ & $\mathrm{SO}_{4}^{2-}$ & $\mathrm{Cl}^{-}$ & $\mathrm{pH}$ & cond & $\mathrm{T}$ & altitude & $\mathrm{Na}^{+}$ & $\mathrm{K}^{+}$ & $\mathrm{Ca}^{2+}$ & $\mathrm{Mg}^{2+}$ \\
\hline W001 & 2.3 & 0.25 & 0.01 & 8 & 34 & 5.56 & 136 & 10.2 & 750 & 17.0 & 0.6 & 1.0 & 1.73 \\
\hline W003 & 2.1 & 0.12 & 0.09 & 2 & 103 & 4.67 & 73 & 12.0 & 711 & 4.6 & 0.4 & 0.2 & 0.39 \\
\hline W004 & 2.1 & 0.22 & 0.01 & 4 & 18 & 5.91 & 64 & 14.3 & 717 & 3.6 & 0.1 & 0.2 & 0.35 \\
\hline W005 & & & & & & 5.91 & 64 & 14.3 & 710 & & & & \\
\hline W006 & & & & & & 5.86 & 63 & 14.3 & 710 & & & & \\
\hline W007 & 1.0 & 0.05 & 0.13 & 2 & 153 & 5.15 & 68 & 11.8 & 714 & 5.6 & 0.4 & 0.3 & 0.45 \\
\hline W009 & 3.8 & 1.10 & 0.05 & 13 & 24 & 4.80 & 66 & 15.0 & 711 & 4.1 & 0.3 & 0.2 & 0.39 \\
\hline W010 & & & & & & 4.50 & 115 & 14.6 & 709 & & & & \\
\hline W011 & 1.4 & 0.27 & 0.01 & 4 & 13 & 5.08 & 86 & 13.8 & 710 & 5.5 & 0.5 & 0.3 & 0.55 \\
\hline W012 & 1.3 & 0.12 & 0.01 & 4 & 22 & 5.57 & 80 & 13.8 & 700 & 12.9 & 1.0 & 0.8 & 1.14 \\
\hline W013 & & & & & & 5.57 & 80 & 13.8 & 700 & & & & \\
\hline W016 & & & & & & 5.54 & 84 & 17.2 & 701 & & & & \\
\hline W017 & 10.2 & 0.54 & 0.17 & 14 & 49 & 5.39 & 56 & 14.5 & 706 & 6.5 & 0.4 & 0.5 & 0.59 \\
\hline W018 & & & & & & 5.39 & 56 & 14.5 & 706 & & & & \\
\hline W019 & 1.05 & 0.05 & 0.01 & 2 & 19 & 5.03 & 62 & 15.5 & 710 & 6.7 & 0.1 & 0.4 & 0.53 \\
\hline W020 & & & & & & 5.03 & 62 & 15.5 & 710 & & & & \\
\hline W022 & 2.3 & 0.05 & 0.01 & 2 & 12 & 5.84 & 40 & 14.8 & 713 & 6.1 & 0.1 & 0.5 & 0.43 \\
\hline W023 & & & & & & 5.84 & 40 & 14.8 & 713 & & & & \\
\hline W025 & 2.9 & 0.26 & 0.01 & 2 & 13 & 5.58 & 50 & 13.9 & 716 & 4.4 & 0.1 & 0.2 & 0.28 \\
\hline W027 & 1.7 & 0.12 & 0.01 & 2 & 19 & 5.48 & 57 & 13.6 & 715 & 6.4 & 0.3 & 0.5 & 0.58 \\
\hline W028 & & & & & & 5.48 & 57 & 13.6 & 715 & & & & \\
\hline W030 & & & & & & 5.24 & 56 & 13.2 & 715 & & & & \\
\hline W031 & 5.3 & 15.2 & 1.58 & 56 & 247 & 6.90 & 1057 & 19.5 & 10 & 126 & 33.8 & 6.0 & 9.96 \\
\hline W032 & & & & & & 6.90 & 1057 & 19.5 & 10 & & & & \\
\hline W033 & 0.31 & 0.09 & 0.06 & 10 & 63 & 5.81 & 239 & 17.0 & 220 & 35.5 & 1.3 & 4.1 & 4.62 \\
\hline W034 & & & & & & 5.81 & 239 & 17.0 & 220 & & & & \\
\hline W035 & 0.29 & 0.05 & 0.01 & 6 & 42 & 4.14 & 167 & 17.1 & 386 & 24.2 & 1.8 & 1.6 & 2.48 \\
\hline W036 & & & & & & 4.35 & 138 & & 398 & & & & \\
\hline W037 & 2.0 & 0.05 & 0.20 & 20 & 63 & 7.82 & 627 & 13.0 & 20 & 41.0 & 4.2 & 22.2 & 12.6 \\
\hline W038 & & & & & & 7.82 & 627 & 13.0 & 20 & & & & \\
\hline W039 & 2.1 & 0.05 & 0.07 & 19 & 61 & 7.94 & 1126 & 12.0 & 73 & 42.1 & 4.1 & 20.7 & 12.8 \\
\hline W040 & & & & & & 7.94 & 1126 & 12.0 & 73 & & & & \\
\hline W041 & 0.21 & 0.05 & 0.08 & 21 & 34 & 8.49 & 316 & 12.0 & 132 & 25.5 & 3.2 & 20.2 & 12.2 \\
\hline W042 & & & & & & 8.58 & 325 & 11.0 & 78 & & & & \\
\hline W043 & 0.07 & 0.05 & 0.06 & 22 & 33 & 8.58 & 325 & 11.0 & 78 & 25.4 & 3.2 & 20.3 & 12.3 \\
\hline W044 & & & & & & 7.83 & 293 & 13.0 & 69 & & & & \\
\hline W045 & 0.28 & 0.20 & 0.11 & 17 & 39 & 7.83 & 293 & 13.0 & 69 & 19.1 & 2.0 & 9.5 & 6.15 \\
\hline
\end{tabular}


Table 1 Cont.

\begin{tabular}{|c|c|c|c|c|c|c|c|c|c|c|c|c|c|}
\hline sample & $\begin{array}{l}\mathrm{NO}^{2-} \\
+\mathrm{NO}^{3-}\end{array}$ & $\mathrm{NH}_{4}^{+}$ & $\mathrm{PO}_{4}^{3-}$ & $\mathrm{SO}_{4}^{2-}$ & $\mathrm{Cl}^{-}$ & $\mathrm{pH}$ & cond & $\mathrm{T}$ & altitude & $\mathrm{Na}^{+}$ & $\mathrm{K}^{+}$ & $\mathrm{Ca}^{2+}$ & $\mathrm{Mg}^{2+}$ \\
\hline W046 & & & & & & 6.18 & 444 & 14.0 & 600 & & & & \\
\hline W047 & 0.02 & 0.05 & 0.01 & 7 & 28 & 6.18 & 444 & 14.0 & 600 & 16.2 & 0.4 & 1.1 & 1.60 \\
\hline W048 & 0.13 & 0.05 & 0.01 & 5 & 17 & 5.40 & 67 & 8.5 & 739 & 10.3 & 0.4 & 0.7 & 0.95 \\
\hline W049 & & & & & & 5.40 & 67 & 8.5 & 739 & & & & \\
\hline W050 & 0.60 & 0.05 & 0.0 & 6 & 17 & 6.70 & 69 & 14.0 & 570 & 11.4 & 0.1 & 0.7 & 0.98 \\
\hline W051 & & & & & & 6.70 & 69 & 14.0 & 570 & & & & \\
\hline W052 & & & & & & 6.76 & 54 & 17.0 & 757 & & & & \\
\hline W053 & & & & & & 6.10 & 68 & 16.0 & 758 & & & & \\
\hline W056 & & & & & & 6.44 & 68 & 15.0 & 759 & & & & \\
\hline W058 & & & & & & 6.03 & 46 & 16.0 & 748 & & & & \\
\hline W059 & 0.02 & 0.05 & 0.08 & 7 & 27 & 6.80 & 46 & 14.0 & 742 & 9.8 & 12.5 & 0.6 & 0.76 \\
\hline W060 & & & & & & 6.80 & 46 & 14.0 & 742 & & & & \\
\hline W062 & 0.02 & 0.05 & 0.01 & 6 & 15 & 6.59 & 46 & 16.0 & 749 & 8.8 & 0.1 & 0.7 & 0.76 \\
\hline W063 & & & & & & 6.59 & 46 & 16.0 & 749 & & & & \\
\hline W064 & & & & & & 6.13 & 88 & 13.0 & 711 & & & & \\
\hline W065 & 0.02 & 0.05 & 0.04 & 7 & 27 & 6.13 & 88 & 13.0 & 711 & 12.2 & 7.9 & 1.1 & 1.21 \\
\hline W067 & 0.02 & 0.05 & 0.01 & 7 & 17 & 6.47 & 62 & 15.0 & 720 & 12.1 & 0.1 & 1.0 & 1.06 \\
\hline W068 & & & & & & 6.47 & 62 & 15.0 & 720 & & & & \\
\hline W069 & 0.02 & 0.05 & 0.01 & 7 & 20 & 5.75 & 81 & 15.0 & 706 & 14.0 & 0.4 & 1.0 & 1.35 \\
\hline W070 & & & & & & 5.75 & 81 & 15.0 & 706 & & & & \\
\hline W072 & & & & & & 5.94 & 74 & 13.0 & 676 & & & & \\
\hline W074 & & & & & & 5.47 & 43 & 14.0 & 697 & & & & \\
\hline W076 & 0.02 & 0.05 & 0.01 & 5 & 14 & 5.06 & 55 & 13.0 & 717 & 9.6 & 0.4 & 0.6 & 0.93 \\
\hline W078 & & & & & & 5.02 & 47 & 12.0 & 717 & & & & \\
\hline W080 & & & & & & 4.98 & 78 & 15.0 & 717 & & & & \\
\hline W082 & 0.02 & 0.05 & 0.01 & 6 & 17 & 5.22 & 48 & 15.0 & 724 & 9.1 & 0.4 & 0.4 & 0.76 \\
\hline W084 & & & & & & 4.93 & 57 & 15.0 & 724 & & & & \\
\hline W085 & & & & & & 5.22 & 47 & 14.0 & 725 & & & & \\
\hline W087 & & & & & & 5.30 & 76 & 15.0 & 724 & & & & \\
\hline W089 & & & & & & 5.39 & 44 & 15.0 & 727 & & & & \\
\hline W091 & & & & & & 5.79 & 57 & 16.0 & 725 & & & & \\
\hline W093 & & & & & & 5.78 & 76 & 14.0 & 725 & & & & \\
\hline W095 & 0.02 & 0.05 & 0.01 & 10 & 13 & 5.58 & 45 & 15.0 & 724 & 8.0 & 0.1 & 0.7 & 0.62 \\
\hline W097 & 0.02 & 0.05 & 0.01 & 7 & 19 & 4.98 & 67 & 13.0 & 739 & 10.3 & 0.4 & 0.6 & 0.78 \\
\hline W098 & & & & & & 4.98 & 67 & 13.0 & 739 & & & & \\
\hline W100 & & & & & & 4.76 & 62 & 13.0 & 743 & & & & \\
\hline W101 & 0.02 & 0.05 & 0.01 & 8 & 18 & 4.71 & 69 & 13.0 & 738 & 7.4 & 0.4 & 0.5 & 0.66 \\
\hline
\end{tabular}


Table 1 Cont.

\begin{tabular}{|c|c|c|c|c|c|c|c|c|c|c|c|c|c|}
\hline sample & $\begin{array}{l}\mathrm{NO}^{2-} \\
+\mathrm{N}^{3-}\end{array}$ & $\mathrm{NH}_{4}^{+}$ & $\mathrm{PO}_{4}^{3-}$ & $\mathrm{SO}_{4}^{2-}$ & $\mathrm{Cl}^{-}$ & $\mathrm{pH}$ & cond & $\mathrm{T}$ & altitude & $\mathrm{Na}^{+}$ & $\mathrm{K}^{+}$ & $\mathrm{Ca}^{2+}$ & $\mathrm{Mg}^{2+}$ \\
\hline W104 & & & & & & 5.32 & 83 & 11.0 & 804 & & & & \\
\hline W108 & & & & & & 5.13 & 50 & 13.0 & 738 & & & & \\
\hline W111 & 0.02 & 0.05 & 0.01 & 8 & 19 & 5.19 & 73 & 12.0 & 745 & 12.0 & 0.5 & 0.8 & 1.12 \\
\hline W113 & 0.02 & 0.05 & 0.01 & 8 & 18 & 4.89 & 71 & 13 & 742 & 12.6 & 0.1 & 0.8 & 1.09 \\
\hline W116 & 0.02 & 0.05 & 0.01 & 7 & 18 & 5.54 & 55 & 15.0 & 726 & 11.1 & 0.1 & 0.8 & 0.94 \\
\hline W118 & 0.02 & 0.05 & 0.01 & 5 & 15 & 5.42 & 60 & 14.0 & 707 & 9.9 & 0.1 & 0.7 & 0.86 \\
\hline W119 & & & & & & 5.42 & 60 & 14.0 & 707 & & & & \\
\hline W121 & & & & & & 7.15 & 329 & 15.0 & & & & & \\
\hline W122 & & & & & & 7.15 & 329 & 15.0 & & & & & \\
\hline W123 & 0.18 & 0.05 & 0.01 & 5 & 17 & 5.03 & 62 & 12.0 & 675 & 7.6 & 0.1 & 0.6 & 0.71 \\
\hline W124 & 0.27 & 0.05 & 0.02 & 17 & 143 & 6.21 & 487 & 14.0 & 131 & 77.6 & 1.9 & 7.0 & 9.64 \\
\hline W125 & 0.02 & 0.05 & 0.01 & 21 & 171 & 6.05 & 595 & 13.0 & 135 & 58.7 & 1.1 & 4.5 & 7.84 \\
\hline W126 & & & & & & & 240 & 14.0 & 121 & & & & \\
\hline W127 & 0.02 & 0.05 & 0.01 & 10 & 63 & 6.38 & 240 & 14.0 & 121 & 40.0 & 1.0 & 3.1 & 4.72 \\
\hline W128 & 0.02 & 0.05 & 0.01 & 9 & 55 & 6.14 & 223 & 13.0 & 121 & 36.9 & 1.0 & 2.6 & 4.04 \\
\hline W129 & 0.02 & 0.05 & 0.01 & 12 & 96 & 6.36 & 358 & 14.0 & 163 & 52.5 & 1.7 & 5.7 & 6.24 \\
\hline W130 & 0.02 & 0.05 & 0.35 & 137 & 1062 & 6.44 & 3440 & 17.0 & 78 & 632 & 23.0 & 30.2 & 63.9 \\
\hline W131 & & & & & & 6.44 & 3440 & 17.0 & 78 & & & & \\
\hline W132 & & & & & & 8.46 & 235 & 16.0 & 59 & & & & \\
\hline W133 & & & & & & 8.46 & 235 & 16.0 & 59 & & & & \\
\hline
\end{tabular}

In 1949, a scientific and meteorological station, Martin-deViviès, was established on the north-eastern coast. Since 2006 the island gained the status of Nature Reserve and a management plan is currently in place to provide greater protection for the environment and its biota (LEBOUVIER \& FRENOT 2007).

Sampling. A total of 133 diatom samples were collected during November and December 2007. Sampling locations were chosen in order to represent a maximum variability of habitat types ranging from small streams, lakes, bogponds and temporary pools from all over the island. The samples were collected in PVC bottles and fixed with 3\% formaldehyde. Each sample was geographically localized using GPS and was accompanied by a detailed site description. In situ, $\mathrm{pH}$, specific conductance, water temperature and oxygen have been measured for all samples using a WTW 340i Multimeter. For 46 of them, water has been collected 20 $\mathrm{cm}$ below the surface, filtered in situ and deep-frozen to be subsequently analysed in the laboratory at the University of Antwerp. Table 1 lists all samples together with their chemical characteristics. In the frozen water samples $\mathrm{NO}_{2}{ }^{-}+\mathrm{NO}_{3}{ }^{-} \mathrm{N}$, $\mathrm{NH}_{4}^{+}-\mathrm{N}, \mathrm{PO}_{4}^{3-}-\mathrm{P}, \mathrm{SO}_{4}^{2-}, \mathrm{Cl}^{-}, \mathrm{Na}^{+}, \mathrm{K}^{+}, \mathrm{Mg}^{2+}, \mathrm{Ca}^{2+}, \mathrm{Fe}^{2+}$ were analysed at the Laboratory for Ecosystem Management (University of Antwerp, Belgium) using a continuous flow analysis (CFA-SKALAR).

Slide preparation and counting. A selection of 95 samples (out of 133) was further surveyed for diatoms, including all 46 samples with full chemical analysis. Diatom samples were prepared following the method described in VAN DER WERFF (1955). Small quantities of the samples were cleaned by adding $37 \% \mathrm{H}_{2} \mathrm{O}_{2}$ and heating to $80{ }^{\circ} \mathrm{C}$ for about $1 \mathrm{~h}$. The reaction was completed by addition of $\mathrm{KMnO}_{4}$. Following digestion and centrifugation, the resulting clean material was diluted with distilled water to avoid excessive concentrations of diatom valves that may hinder reliable observations. Cleaned diatom valves were mounted in Naphrax ${ }^{\circledR}$. Samples and slides are stored at the National Botanic Garden of Belgium (BR), Department of Bryophytes and Thallophytes. In each sample, 400 diatom valves were identified and enumerated on random transects at $1000 \times$ magnification using an Olympus BX51 microscope equipped with Differential Interference Contrast (Nomarski) optics. Slides have been scanned after doing the 400 valves counts in order to find rare species. Identifications of Antarctic and subAntarctic species are based on descriptions by BOURRELLY \& Manguin (1954), Le Cohu \& Maillard (1983, 1986), Schmidt et al. (1990), OpPenheim (1994), VAn de ViJVer et al. (2002a, 2004b, 2008b, 2011, 2012) and Le CoHU (2005). 
Nomenclature follows VAN DE VIJVER et al. 2002a.

Data analysis. For a pair wise comparison of the diatom flora of Ile Amsterdam with those of the other sub-Antarctic islands of the southern Indian Ocean Province (Prince Edward Islands, Iles Crozet, Iles Kerguelen, Heard Island) the Community Coefficient of SørEnsen (1948) is used. This index has the following formula: $2 \mathrm{c} /(\mathrm{a}+\mathrm{b}+2 \mathrm{c})$ where $\mathrm{a}$ and $\mathrm{b}$ are the numbers of species exclusively observed in each of the two sites and $\mathrm{c}$ is the number of species shared by these sites.

To evaluate the extent to which our sampling effort represented the diatom flora in the waterbodies of Ile Amsterdam, we calculated the incidence-based species richness estimator (ICE, CHAO et al. 2000) and the mean Chao2 richness estimator (СНАO 1984), both using the EstimateS program version 8.2 (Colwell 2009). ShannonWiener diversity index ( $\log 10$-based) and Hill's evenness index were calculated using the statistical package MVSP.

Ordination was used to show the patterns in species composition. The statistical analysis was performed using CANOCO version 4.5 (TER BRAAK \& ŠMilauer 2002). Square root-transformed abundance data were used in the ordinations.

Principal Components Analysis (PCA) was used to determine the main directions of variation in the water chemistry dataset. Fe was removed from the original data set since most of its values were below the limit of detection. All environmental variables, except for $\mathrm{pH}$ and temperature, were $\log$-transformed since they had skewed distributions. After this transformation, no skewed distributions were shown. Detrended Correspondence Analysis (DCA) was carried out to estimate gradient length. The results showed that two samples (W031, W032), subject to excessive marine influence (sampled from a pool in the middle of a large fur seal colony) were considered to be outliers. A DCA with the outliers omitted showed gradient lengths for the first four axes of 4.5, 3.8, 2.3, and 2.9, suggesting that methods based on unimodal models (Canonical Correspondence Analysis) would be appropriate for a subsequent ordination (TER BRAaK \& Prentice 1988). A CCA with 46 samples (for which physic-chemical data were available) was used to detect patterns of variation in the species data that can be explained by environmental variables. All other samples were added as passive samples. Since not all of the 13 environmental variables influence the diatom distributions independently, we used Canonical Correspondence Analysis (CCA) with forward selection and unrestricted Monte Carlo permutation tests (999 permutations, $\mathrm{P} \leq 0.05$ ). All statistical and numerical techniques used in this study are described in full detail in Jongman et al. (1995).

\section{Results}

\section{Water chemistry}

The major patterns of variation within the chemistry data are revealed based on a Principal Component Analysis (Fig. 2). Based on its extreme high conductivity value, sample W130 was removed from the analysis. Small angles between biplot arrows indicate generally high positive correlations. Environmental variables that explain most of the variation, are represented by the longest arrows aligned along the axes and hence are more important. PCA axis 1 accounts for $64 \%$ of the variance $\left(\lambda_{1}=0.643\right)$ in the data set and reflects two, strongly negatively correlated main gradients: on one hand altitude and on the other $\mathrm{pH}$ and specific

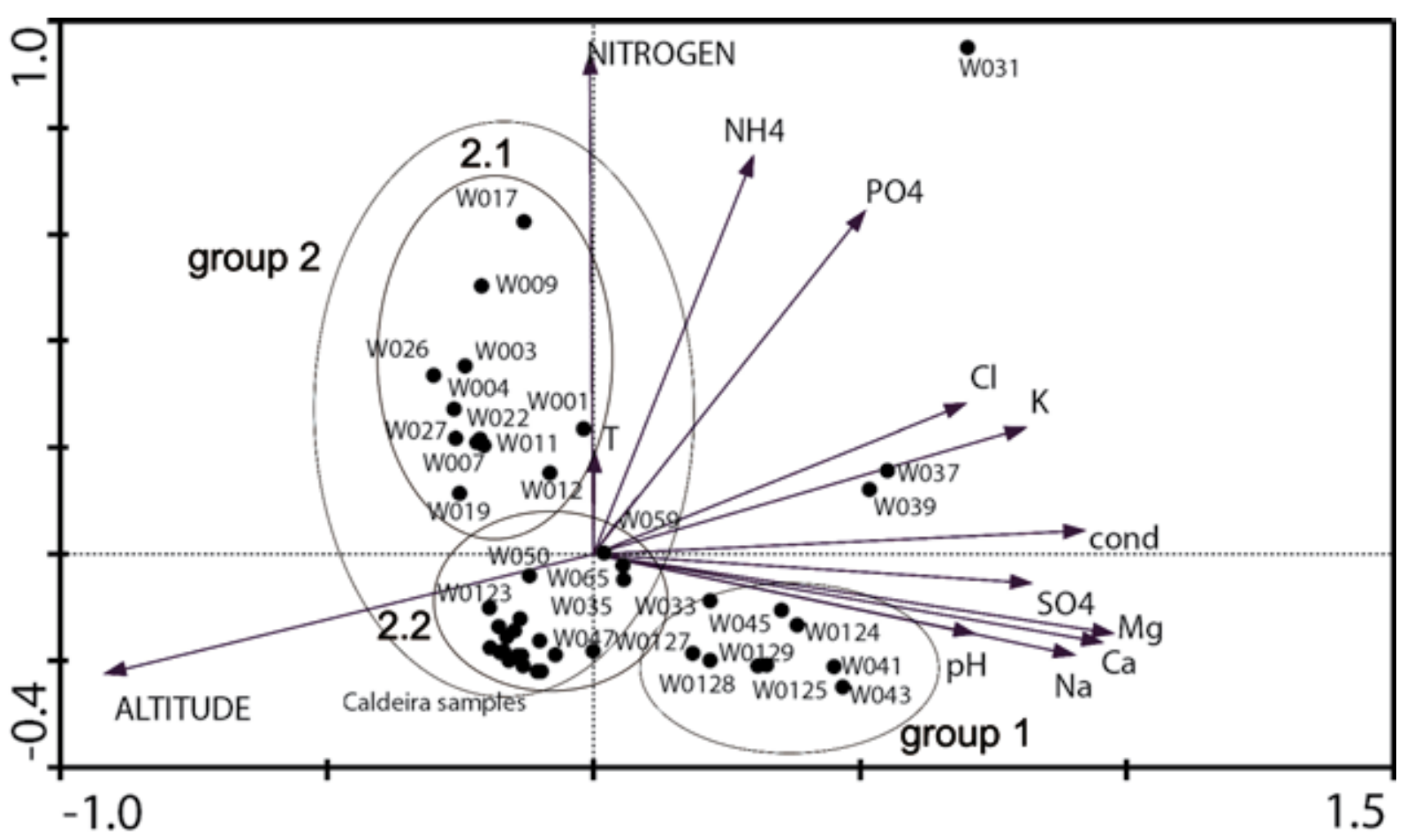

Fig. 2. A correlation biplot of samples and environmental variables resulting from the Principal Components Analysis of the water chemistry dataset. 
conductance, the latter being highly linked to $\mathrm{Cl}^{-}, \mathrm{Na}^{+}$, $\mathrm{Ca}^{2+}, \mathrm{K}^{+}, \mathrm{Mg}^{2+}$ and $\mathrm{SO}_{4}^{2-}$. Axis 2 seems less important and accounts for only $17 \%$ of the variance $\left(\lambda_{2}=0.165\right)$ and is most likely reflecting a nitrogen gradient. Sample W031, situated in the upper left part of the diagram, is set somewhat apart from the other samples without being considered a complete outlier. This sample has the highest ammonium $\left(\mathrm{NH}_{4}^{+}-\mathrm{N}\right)$ and phosphate $\left(\mathrm{PO}_{4}^{3-}\right.$ -P) load most likely caused by animal influence as the sample was taken from a pool in the fur seal colony close to the sea. Two major groups of samples can be recognized. A first group contains all samples collected at Pointe Del Cano and Pointe d'Entrecasteaux showing high amounts of the above mentioned ions, whereas the second group is composed of all samples taken from the Caldera region in the centre of the island. The latter group can be subdivided into two parts. A first

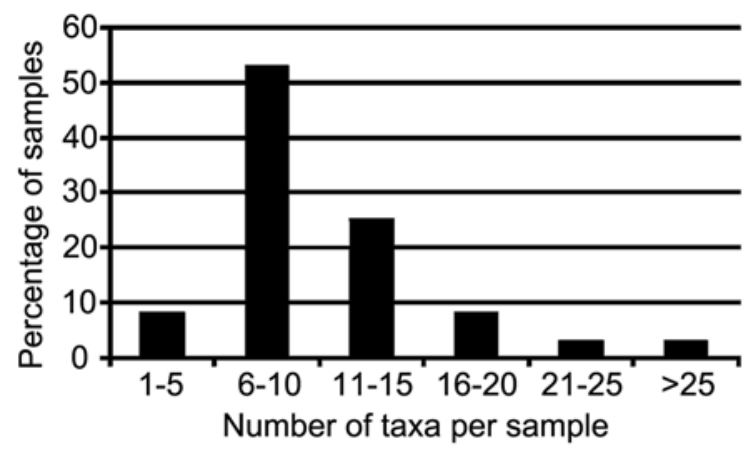

Fig. 3. Frequency distribution of diatom taxa in studied samples.

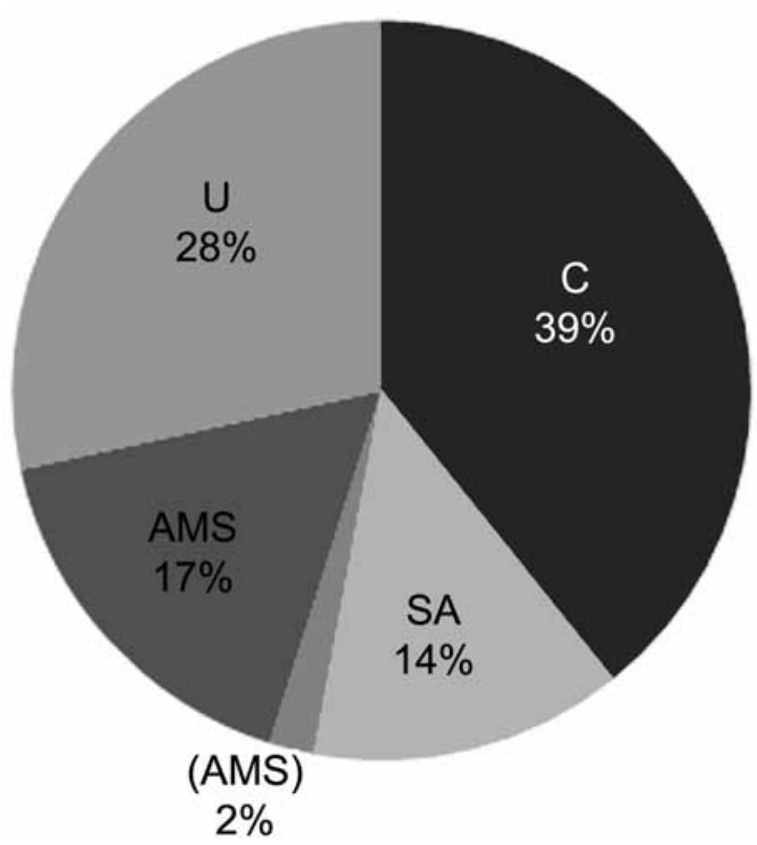

Fig. 4. Distribution of the species according to their biogeographical distribution [Distribution: (C) cosmopolitan, (AMS) Ile Amsterdam, (SA) subantarctic region, (U) unknown, ((AMS)) - Ile Amsterdam but yet undescribed]. subgroup (2.1) contains only samples from the lowest plateau in the Caldera, immediately in the vicinity of the Museau de Tanche crater. These samples are characterized by elevated nitrogen values (1.0-10.2 $\mathrm{mg} / \mathrm{l})$ and are separated from all other samples in the Caldera region forming subgroup 2.2, characterized by low nitrogen values $\left(<0.8 \mathrm{mg} \cdot \mathrm{l}^{-1}\right)$.

Species composition and the similarity analysis. A total of 98 diatom taxa (including species, varieties and forms) belonging to 33 genera has been found during the analysis of 95 freshwater samples. Six additional taxa were observed outside the counts bringing the total number of diatoms in our samples up to 104. Table 6 provides a full list of all species observed in this study together with the biogeographical distribution of the taxa.

Using species richness estimators, it is possible to evaluate how well the sampling effort reflected the true diatom species richness. The expected total number of taxa in all samples is 110 (ICE) or 113 (Chao2), suggesting that the counting protocol scored between 87 and $89 \%$ of the total taxa present in the samples overall.

Species richness per sample ranged from 1 to 27 . Two samples were entirely monospecific, composed of only Eunotia paludosa GRUNOW (W007 \& W009). The distribution of species numbers per sample (Fig. 3 ) showed that most samples contained between 6 and 10 taxa per sample with an average number of taxa per sample of $11 \pm 5$. Table 2 lists all genera arranged according to their species number. The most species rich genera include Pinnularia (20 species), Nitzschia (11 species), Diadesmis (9 species), Luticola (6 species) and Eunotia ( 5 species). The five most abundant species made up $66.2 \%$ of all the diatoms counted: Frustulia lebouvieri VAN DE VIJVER et GREMMEN (30.8\%), Eunotia paludosa (9.8\%), Kobayasiella subantarctica VAn de ViJver et Vanhoutte (9.7\%), Planothidium subantarcticum VAN DE VIJVER et C.E.WETZEL (8.6\%) and Eunotia muscicola KRASSKE (7.3\%). On the other side of the abundance scale, 83 taxa (more than $85 \%$ of all counted taxa) had a total relative abundance of less than $1 \%$.

Detailed scanning electron microscopy analysis observations revealed the presence of several recently described species, mostly within the genus Pinnularia such as $P$. australogibba VAN DE VIJVER, ChATtová et Metzeltin or $P$. amsterdamensis Chattová, Metzeltin et VAN DE VIJVER. Additionally, three recently described species were found during a survey of lava tube sample W033: Mayamaea cavernicola VAn de ViJver, Sellaphora barae VAN DE VIJVER and Orthoseira verleyenii VAN DE VIJVER. A large number of taxa $(12 \%)$ could at present only be identified up to the genus level, mostly within the genera Amphora, Diadesmis and Luticola.

Based on the biogeographic distribution of the 


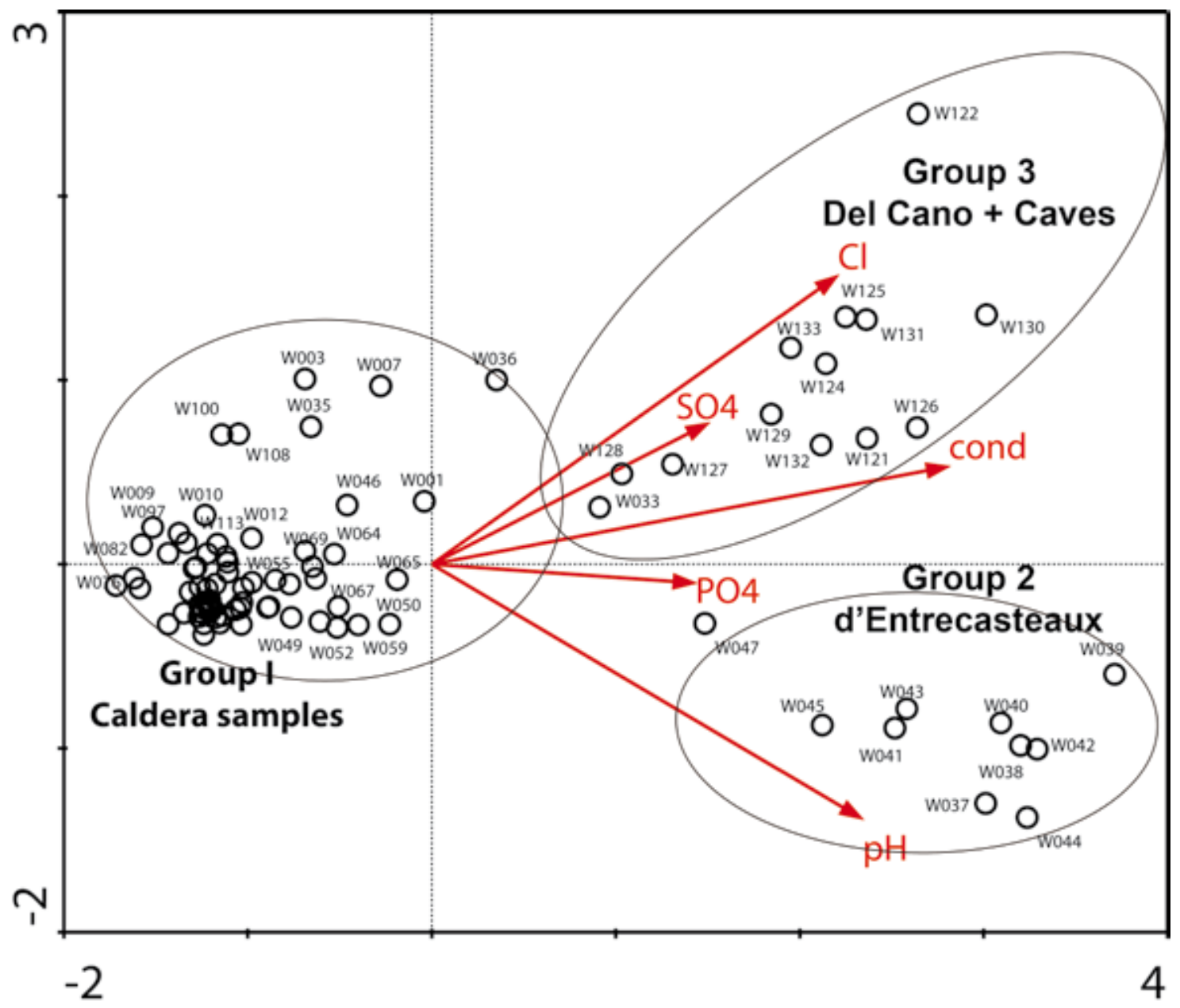

Fig. 5. Canonical Correspondence Analysis (CCA) correlation biplot of samples versus environmental variables based on species relative abundance data. The different groups (except group 4) are indicated on the diagram. The CCA-analysis was based on 46 samples for which a complete set of physic-chemical data were available. The other samples were added as passive samples.

taxa, it is clear that the Amsterdam freshwater diatom flora is composed of cosmopolitan, sub-Antarctic and endemic elements (Fig. 4). Almost $17 \%$ of all recorded taxa can be considered endemic to Ile Amsterdam, most of them belonging to the genus Pinnularia. An additional $14 \%$ of the taxa show an exclusive subAntarctic distribution such as Achnanthes naviformis VAn DE VIJVER et Beyens, Frustulia lebouvieri and Kobayasiella subantarctica.

A similarity analysis based on presence/absence data was performed between the Ile Amsterdam diatom flora with the floras from the other islands in the southern Indian Ocean Province (Prince Edward Islands, Iles Crozet, Iles Kerguelen and Heard Island). Based on this presence/absence list of the Ile Amsterdam taxa, the Ile Amsterdam diatom flora shows a low affinity with the diatom floras of the true subAntarctic islands in the southern Indian Ocean with SøRENSEN similarity coefficients ranging between 0.28 and 0.29 (Table 3 ). The low similarity values are most likely the consequence of both a low total number of species on Ile Amsterdam and a low number of shared species. Typical shared sub-Antarctic taxa include
Achnanthes muelleri CARLSON, Achnanthes naviformis, Chamaepinnularia aerophila VAN DE VIJVER et BEYENS, Diadesmis vidalii VAN DE VIJVER, LEDEGANCK et BEYENS and Diadesmis crozetikerguelensis LE COHU et VAN DE VIJVER.

Diatom community analysis. The initial dataset of 95 samples and 98 diatom taxa was used in the multivariate analysis. After a first analysis, two samples were removed from the analysis as outliers (W031 \& W032). The original set of 13 environmental variables was reduced to five. Potassium $\left(\mathrm{K}^{+}\right)$, Sodium $\left(\mathrm{Na}^{+}\right)$, Magnesium $\left(\mathrm{Mg}^{2+}\right)$ and Calcium $\left(\mathrm{Ca}^{2+}\right)$ were highly correlated to specific conductance and therefore removed from the analysis. Forward selection with Monte Carlo unrestricted permutations (999 permutations) identified specific conductance, $\mathrm{Cl}^{-}$, $\mathrm{SO}_{4}{ }^{2-}, \mathrm{PO}_{4}{ }^{2-}$ and $\mathrm{pH}$ as the environmental variables that explain significant variation in the diatom data $(\mathrm{P}<0.05)$. The CCA restrained to these five selected variables explained only $28.7 \%$ of the species variance. This is low but typical for noisy data sets with many blank values (STEVEnson et al. 1991). The first two 
Table 2. Genera ordered by decreasing percentual portion (\%) calculated on the number of the taxa (n).

\begin{tabular}{|c|c|c|}
\hline & $\mathbf{n}$ & $\%$ \\
\hline Pinnularia & 21 & 20.2 \\
\hline Nitzschia & 10 & 9.6 \\
\hline Diadesmis & 9 & 8.7 \\
\hline Luticola & 6 & 5.8 \\
\hline Eunotia & 5 & 4.8 \\
\hline Achnanthes & 4 & 3.8 \\
\hline Navicula & 4 & 3.8 \\
\hline Stauroneis & 4 & 3.8 \\
\hline Gomphonema & 3 & 2.9 \\
\hline Mayamaea & 3 & 2.9 \\
\hline Pinuavis & 3 & 2.9 \\
\hline Planothidium & 3 & 2.9 \\
\hline Psammothidium & 3 & 2.9 \\
\hline Sellaphora & 3 & 2.9 \\
\hline Amphora & 2 & 1.9 \\
\hline Frustulia & 2 & 1.9 \\
\hline Hantzschia & 2 & 1.9 \\
\hline Orthoseira & 2 & 1.9 \\
\hline Achnanthidium & 1 & 1.0 \\
\hline Caloneis & 1 & 1.0 \\
\hline Chamaepinularia & 1 & 1.0 \\
\hline Craticula & 1 & 1.0 \\
\hline Denticula & 1 & 1.0 \\
\hline Karayevia & 1 & 1.0 \\
\hline Kobayasiella & 1 & 1.0 \\
\hline Lecohuia & 1 & 1.0 \\
\hline Melosira & 1 & 1.0 \\
\hline Opephora & 1 & 1.0 \\
\hline Placoneis & 1 & 1.0 \\
\hline Pseudostaurosira & 1 & 1.0 \\
\hline Rhopalodia & 1 & 1.0 \\
\hline Stauroforma & 1 & 1.0 \\
\hline Tryblionella & 1 & 1.0 \\
\hline Total & 104 & \\
\hline
\end{tabular}

axes account for $79.6 \%$ of the cumulative variance. The first two axes $\left(\lambda_{1}=0.709, \lambda_{2}=0.228\right)$ were highly significant $(\mathrm{p}<0.001)$ (TER BRAAK \& ŠMILAUER 2002). CCA axis 1 is strongly correlated with specific conductance (inter-set correlation $=0.88$ ) and to a lesser extent with $\mathrm{pH}(0.73)$ and $\mathrm{Cl}^{-}(0.68)$ whereas CCA axis 2 is correlated with $\mathrm{Cl}^{-}(0.52)$ and negatively with $\mathrm{pH}(-0.46)$. The CCA diagram (Fig. 5) shows three main groups of samples. Table 4 lists the relevant (measured) ecological parameters, together with mean species diversity, mean evenness and mean number of taxa. Samples W031 and W032, considered outliers and not taken into account in the CCA, were added as a fourth group since both were taken from the same pool in the fur seal colony. The dominant and subdominant species observed in each group are shown in Table 5.

The first group, situated in the left part of the diagram, is composed exclusively of high-altitude very acid lakes with low specific conductance, nutrient and ion values. These lakes are characterized by Eunotia muscicola, Frustulia lebouvieri and Kobayasiella subantarctica. Additionally, Pinnularia vixconspicua Chattová, Van de Vijver et Metzeltin and E. lecohui VAN DE VIJVER, though in general rather rare on the island, show a remarkable abundance in these lakes. The second group, found in the lower right part of the diagram, contains all samples collected from streams and pools in the vicinity of Falaise d'Entrecasteaux, located in the southern part of the island. These samples have higher $\mathrm{pH}$ values $(8.2 \pm 0.4)$ and a higher conductivity, $\mathrm{SO}_{4}^{2-}, \mathrm{Mg}^{2+}, \mathrm{Ca}^{2+}$ and $\mathrm{K}^{+}$values. Dominant taxa include Planothidium subantarcticum, Navicula gregaria DonkIN, Navicula veneta KÜTZING and Sellaphora seminulum (GRUNOw) D.G.MANN. The third group is composed of samples from two localities: all samples from the Del Cano region in the southern part of the island together with four samples taken in small cave pools located in the Grand Tunnel near the scientific base in the northern part of Ile Amsterdam. The samples are characterized by a slightly acid $\mathrm{pH}$, higher specific conductance values and higher $\mathrm{Cl}^{-}$and $\mathrm{Na}^{+}$values, possibly the result of increased sea-spray input. The samples are dominated by Planothidium subantarcticum, Karayevia oblongella (Østrup) M.Aboal, Achnanthidium cf. minutissimum (Kützing) CZARnecki, Melosira sp. and several Diadesmis taxa. The last group (not represented in the Canoco Analysis) is based on only two samples (W031 and W032) that were left out as outliers. Both samples, showing very high specific conductance, $\mathrm{SO}_{4}{ }^{2-}, \mathrm{N}$ and $\mathrm{PO}_{4}{ }^{2-}$ concentrations, were taken from a large rocky pool in the middle of a large fur seal colony and are dominated by Pinnularia subacoricola Metzeltin, Lange-Bertalot et García-Rodríguez, Nitzschia palea (KütZING) W.SMItH and Luticola sp1 with Mayamaea permitis (HUSTEDT) K.BRUDER et MEDLIN and Pinnularia australogibba var. subcapitata Van de Vijver, Chattová et Metzeltin often being subdominant. 


\section{Discussion}

\section{Species composition and general biogeography}

The low similarity values based on presence/absence data between Ile Amsterdam and the other islands are not surprising considering the low number of species observed at the sites, the differences in the microhabitat diversity, the rather large distance between the islands, the very isolated position of Ile Amsterdam and the relative young geological age. Similar results can be found in the species composition of other organisms such as higher plants, mosses and lichens (АРтRоOT et al. 2011). The sub-Antarctic islands, grouped by Stonehouse (1982) in the so-called "cold-temperate sub-Antarctic Region" whereas Ile Amsterdam is located in the "warm-temperate sub-Antarctic Region", show a higher diversity of microhabitats such as different types of bogponds, animal wallows, fellfields and lakes, where different diatom floras could develop (VAN DE ViJVER et al. 2008). On Ile Amsterdam, the number of stagnant waterbodies is limited to the acid, Sphagnum-dominated, pools and lakes in the caldera region, showing a rather uniform diatom composition.

It is however true that based on relative abundance data, the situation is somewhat different. Within the five most abundant taxa, three are typical sub-Antarctic taxa and two can even be considered to have a worldwide distribution. The three subAntarctic taxa are confined only to the southern Indian Ocean islands and absent on all other studied Antarctic localities (KoPAlOVÁ \& VAN DE VIJVER 2013; Kopalová et al. 2013). Frustulia lebouvieri was so far only found on the Prince Edward Islands, the most northerly situated sub-Antarctic Islands (VAN DE VIJVER et al. 2008a) whereas the other two species are absent from the most southern sub-Antarctic island (Heard Island; VAN DE VIJVER et al. 2004). Both cosmopolitan taxa belong to the most common taxa in the southern hemisphere and are present, usually in large abundances, on merely every analysed Antarctic locality (KellogG \& Kellogg 2002). This may indicate that these 5 taxa probably a rather broad environmental tolerances, easily capable of adapting to prevailing environmental conditions. It also might indicate that their dispersal to and colonisation of Ile Amsterdam was therefore facilitated. Their overall dominance on Ile Amsterdam is not necessarily related to possible anthropogenic impact although the only way to clearly demonstrate this will be the analysis of Holocene sediment and peat to identify the evolution of the diatom communities on the island. Hypotheses on the human impact is therefore at the moment high speculative and therefore not relevant.

A typical feature of oceanic islands is the fact that the flora and fauna on these islands are usually disharmonic (GILlESPIE 2007). Some genera tend to be overrepresented whereas others are missing or show only a reduced diversity. The diatom flora of Ile Amsterdam proved to be a good example of this rule. As can be seen in Table 2, Pinnularia accounts for more than $20 \%$ of all recorded taxa whereas other typical species-rich genera such as Navicula, Nitzschia or Eunotia are less abundantly present on the island or even completely absent as is the case for Fragilaria. One of the reasons might be the highly specific nature of the Ile Amsterdam environment dominated by the acid Sphagnum-dominated peatland area in the upper Caldera. However, in comparable northern hemisphere environments, genera such as Neidium, Brachysira, Eunotia and Frustulia co-dominate bogponds and heathland fens, often represented by a high number of taxa (e.g., FrÁnKová et al. 2009; LANGE-Bertalot et al. 2011; PoulíčKovÁ et al. 2013). The main reason for this disharmony is most likely the reduced dispersion and colonisation success of these genera followed by an increased speciation of the successful genera. VYVERMAN et al. (2007) already stated that the effect of isolation was particularly high on Ile Amsterdam reducing the genus diversity compared to the other islands, contradicting that way the ongoing discussion on the possible ubiquity of diatoms (FINLAY \& CLARKE 1999). The effect is apparently even more striking based on species level. Only a very low number of taxa are shared with the other islands. Most remarkably is the fact that more than $75 \%$ of these shared taxa show a cosmopolitan, even worldwide, distribution. Typical examples such as Navicula gregaria or Amphora veneta are widespread in the world and seem to be present on every continent (Kellogg \& KellogG 2002; Metzeltin et al. 2009; HofmAnN et al. 2011). Whether these taxa are also genetically similar is an open question. Recent results on the cosmopolitan Pinnularia borealis EHRENBERG showed the presence of several genetically different lineages including a typical Antarctic lineage (Souffreau et al. 2013). Only a minority of the shared species have a restricted sub-Antarctic distribution, confirming previous biogeographic results on the subAntarctic flora (VAN DE VIJVER et al. 2005, 2011). The low similarity also indicates the presence of a highly specific diatom flora on Ile Amsterdam. It is clear from the large number of cf. and sp. taxa in the species list (Table 6) that a large part of the observed species show some affinity with known taxa but at the same time sufficient differences to be separated as independent taxa. Several have been described recently (VAN DE ViJver et al. 2012; VAN DE ViJVER \& Cox 2013; Lowe et al. 2013) whereas some others still await a formal description. Additional morphological analysis will be necessary to reveal their true taxonomic status and it is likely that some of them will need a formal description as new taxa.

It is possible that the geographic isolation combined with the special environmental and climatic conditions resulted in an increased speciation rate, as is often seen on oceanic islands (FLEISCHER et al. 
Table 3. Similarity analysis (Sørensen index) between Ile Amsterdam and other sub-Antarctic localities.

\begin{tabular}{llllll}
\hline & Amsterdam Island & Prince Edward Islands & Kerguelen & Crozet & Heard Island \\
\hline Number of taxa & 104 & 196 & 210 & 220 & 191 \\
Index of Sørensen & - & 0.29 & 0.29 & 0.28 & 0.28 \\
\hline
\end{tabular}

Table 4. Water chemistry and diversity features in the different sample groups identified by the CCA analysis (mean and standard deviation).

\begin{tabular}{|c|c|c|c|c|}
\hline & 1 & 2 & 3 & 4 \\
\hline $\begin{array}{l}\text { number of samples (\#with physico- } \\
\text { chemical data) }\end{array}$ & $70(31)$ & $9(6)$ & $14(8)$ & $2(1)$ \\
\hline number of taxa & $9 \pm 3$ & $15 \pm 5$ & $18 \pm 6$ & $16 \pm 2$ \\
\hline number of genera & $5 \pm 2$ & $12 \pm 2$ & $13 \pm 2$ & $10 \pm 2$ \\
\hline diversity & $1.3 \pm 0.4$ & $1.5 \pm 0.2$ & $1.74 \pm 0.6$ & $2 \pm 0.1$ \\
\hline Evenness & $0.58 \pm 0.17$ & $0.55 \pm 0.07$ & $0.59 \pm 0.17$ & $0.73 \pm 0.08$ \\
\hline $\mathrm{pH}$ & $5.5 \pm 0.6$ & $8.1 \pm 0.3$ & $6.7 \pm 0.9$ & 6.9 \\
\hline specific conductance & $74 \pm 68$ & $562 \pm 326$ & $312 \pm 113$ & 1057 \\
\hline$\left(\mathrm{NO}_{2}{ }^{-}+\mathrm{NO}_{3}^{-}\right) \mathrm{N}$ & $0.9 \pm 1.9$ & $0.9 \pm 0.9$ & $0.11 \pm 0.1$ & 5.3 \\
\hline $\mathrm{NH}_{4}^{+}-\mathrm{N}$ & $0.1 \pm 0.11$ & $0.08 \pm 0.1$ & $0.06 \pm 0.01$ & 15.2 \\
\hline $\mathrm{PO}_{4}{ }^{3-} \mathrm{P}$ & $0.02 \pm 0.03$ & $0.1 \pm 0.1$ & $0.02 \pm 0.01$ & 1.58 \\
\hline $\mathrm{SO}_{4}^{2-}$ & $6 \pm 2.5$ & $19.8 \pm 1.7$ & $13 \pm 4.3$ & 56 \\
\hline $\mathrm{Cl}^{-}$ & $23 \pm 17$ & $46 \pm 13.2$ & $99 \pm 44$ & 247 \\
\hline $\mathrm{Na}^{+}$ & $10 \pm 3$ & $31 \pm 9$ & $50 \pm 15$ & 126 \\
\hline $\mathrm{K}^{+}$ & $1 \pm 0.1$ & $3.3 \pm 0.8$ & $1.3 \pm 0.3$ & 33.8 \\
\hline $\mathrm{Ca}^{2+}$ & $0.7 \pm 0.2$ & $19 \pm 5$ & $4.5 \pm 1.4$ & 6.0 \\
\hline $\mathrm{Mg}^{2+}$ & $0.9 \pm 0.3$ & $11.2 \pm 2.5$ & $6.2 \pm 1.9$ & 9.96 \\
\hline
\end{tabular}

2008, BuCKLEy et al. 2009). Important genera such as Pinnularia and Eunotia show more than $60 \%$ of taxa that are only found on Ile Amsterdam (VAN DE VIJVER et al. 2009, 2012). Some of these taxa present affinities with cosmopolitan taxa for instance $P$. australogibba is strongly related to $P$. gibba EHRENBERG but differs in several important details to justify a separation as an independent species. Molecular research should make clear how long these taxa have been separated. The analysis of the Pinnularia borealis populations in SOUFFreAu et al. (2013) already discussed this phenomenon. Rapid speciation has been shown before within diatoms. THERIOT et al. (2006) reported, although sometimes contested, on the rapid morphological evolution of the endemic Stephanodiscus yellowstonensis THERIOT et STOERMER that evolved within several thousands of years from
S. niagarae Ehrenberg. Similar results can be seen in other organisms on Ile Amsterdam. Among the seventeen native phanerogamic species reported from Ile Amsterdam, six are endemic to Ile Amsterdam and Ile Saint-Paul (TrÉHEN et al. 1990; GAlley et al. 2007). A lot of these species are nowadays mainly present in the Caldera region, which is quite isolated from the rest of the island. Typical examples of higher plants in the Caldera region include Plantago stauntoni ReichaRdt (Rønsted et al. 2002) and P. pentasperma Hemsley. Recently, several new Sphagnum taxa have been described from Ile Amsterdam (FlatBERG et al. 2011) with all reported species showing a restricted distribution to Ile Amsterdam and/or the neighbouring Ile Saint-Paul. The same applies for the Hepaticae and Anthocerotae flora of the island (GROLLE 2002; VÁŇA et al. 2010), despite the fact that the island is rather 
understudied for these groups.

\section{Freshwater diatom communities}

Both chemistry data and diatom distributions indicate that specific conductance and $\mathrm{pH}$ are the major factors separating the freshwater diatom communities on Ile Amsterdam. The presence of $\mathrm{PO}^{3-}-\mathrm{P}$ as one of the determining factors is yet unclear. A possible explanation is the presence of marine mammals at lower altitude in combination with soil erosion, high winds and seaspray. This may cause a higher phosphorus load in the investigated samples. As can be seen, the samples from the fur seal colony show high levels of phosphorus whereas in the caldera, phosphorus levels are always quite low. The waterbodies in the region near Falaises d'Entrecasteaux and Pointe Del Cano all have a slightly acid to clearly alkaline $\mathrm{pH}$ whereas in the Caldera the waterbodies are strictly acidic. d'Entrecasteaux and Del Cano present a similar habitat on very steep cliffs, the latter more or less taken in the small ravines that were cut out by the rivers. The similar physicochemical characteristics of the small brooks confirm this. Subsequently, the diatom communities also present a high similarity. They are dominated by taxa preferring circumneutral to alkaline conditions such as Planothidium subantarcticum, Sellaphora seminulum, Amphora veneta, several Nitzschia taxa and Rhopalodia rupestris (LeVkov 2009; HofMANN et al. 2011; VAN DE VIJVER et al. 2013). Rivers on Ile de la Possession (Crozet Archipelago) and Iles Kerguelen on the contrary have very high frequencies of various Fragilaria taxa, such as Fragilaria capucina Desmazières, Frankophila maillardii (R.LE CoHu) LANGE-Bertalot and Fragilaria germainii E.Reichardt et Lange-Bertalot (VAN de ViJVer \& Beyens 1999b) whereas lotic waters on Ile Amsterdam completely lack any Fragilaria taxa. The acid diatom community in the Caldera regions differs considerably from similar communities on sub-Antarctic islands. On Ile de la Possession, acid pools such as bogponds and peatland lakes are dominated by Chamaepinnularia soehrensis var. muscicola (J.B.PETERSEN) LANGEBertalot et Krammer, Eunotia paludosa and $E$. muscicola (VAN DE VIJVER \& BEYENS 1999b), the latter two also present in relatively large numbers on Ile Amsterdam. On the contrary, Frustulia lebouvieri and most of the Pinnularia taxa that dominate the Ile Amsterdam peatlands, play a less important role on the sub-Antarctic islands. On the Prince Edward Islands, lakes and ponds are dominated by Aulacoseira principissa VAN DE VIJVER, Psammothidium abundans (Manguin) Bukhtiyarova et Round and Eunotia paludosa (VAN DE VIJVER et al. 2008b). Moving southwards, the acid diatom communities change even more with Stauroforma exiguiformis (LANGEBertalot) Flower, Jones et Round and Aulacoseira principissa as dominant taxa on Iles Kerguelen (VAN DE VIJVER et al. 2001). A major habitat difference between the Caldera region and the sub-Antarctic islands is the overall dominance of Sphagnum taxa as peat forming mosses on Ile Amsterdam whereas on the sub-Antarctic Islands, Sphagnum taxa are completely lacking (FlatBerg et al. 2011). On these islands, the peatland moss vegetation is mostly composed of Rhacomitrium and Sanionia (VAN DE VIJVER et al. 2004a).

The PCA analysis indicated altitude as a contributor to the variation in the sample diversity. This is probably a rather artificial contribution as in the analysis most samples originate either from the Caldera region (at an altitude of $700 \mathrm{~m}$ ) or from the southern part of the island (at almost sea-level). Intermediate samples are not numerous in the analysis. On the other hand, there is a striking difference between the physicchemical composition of the Caldera region and the southern part of the island and as such can altitude be used to indicate the nature of the samples. It is however unclear whether the geological history of the island influenced the chemistry of the waterbodies and subsequently the shaping of their diatom communities on Ile Amsterdam. But based on this history it is possible to develop a plausible hypothesis. Ile Amsterdam has been shaped by two consecutive volcanic episodes. The volcanism on Ile Amsterdam is characterized by the formation of a mostly subalkaline tholeiitic basalt with a high concentration of magnesium (DOUCET et al. 2004). This geochemical composition probably resulted in the formation of the alkaline and slightly acid diatom communities found in the d'Entrecasteaux and Del Cano areas and probably might represent the original habitat for diatom communities on the island. All sampled streams in these areas seep out of the bedrock in the steep cliffs that form the southern shore of Ile Amsterdam and then run for several tens of meters on the lowland area towards the ocean. Most likely, the water originates from the upper Caldera region penetrating the porous underlying basaltic bedrock only to reappear almost at sea level as small but fastflowing streams (VAN DE VIJVER, pers. obs.). The high levels of $\mathrm{Na}^{+}$and $\mathrm{Cl}^{-}$most likely result from seaspray that is deposited continuously in the streams and on the lowlands in combination with soil erosion and strong winds. Whether this is also the case for $\mathrm{Ca}^{2+}$ is unclear. There is no indication of calcareous rocks on the entirely volcanic island. A possible source of the $\mathrm{Ca}^{2+}$ may be the huge colony of the yellow-nose albatross nearby but this is highly speculative and needs to be tested before it can be put forward as an hypothesis. Precipitation at sea level is rather limited (FRENOT \& VALLEIX 1990) making it a less probable source for the continuous streams in the d'Entrecasteaux and Del Cano areas. The large Caldera that was formed during the last volcanic phase (Doucet et al. 2003) constantly receives year round a large amount of precipitation (LEBOUVIER \& FRENOT 2007) enabling the development of thick peat layers, almost exclusively 
Table 5. List of diatom species and their abundance in the four groups (1 to 4$)$ of samples identified by the CCA analysis $[(\mathrm{X})>10 \%,(\mathrm{O})$ $5-10 \%,(+) 2-5 \%,($ o) $2-0.5 \%,(\cdot)<0.5 \%)]$.

\begin{tabular}{|c|c|c|c|c|}
\hline Taxon name & 1 & 2 & 3 & 4 \\
\hline Frustulia lebouvieri & $\mathrm{X}$ & & . & \\
\hline Kobayasiella subantarctica & $\mathrm{X}$ & & . & \\
\hline Eunotia muscicola var. muscicola & $\mathrm{X}$ & & + & \\
\hline Eunotia paludosa var. paludosa & $\mathrm{X}$ & & o & \\
\hline Eunotia lecohui & $\mathrm{O}$ & & & \\
\hline Pinnularia vixconspicua & $\mathrm{O}$ & & . & + \\
\hline Pinnularia perminor & + & & . & \\
\hline Planothidium subantarcticum & o & $\mathrm{X}$ & $\mathrm{X}$ & . \\
\hline Navicula gregaria & . & $\mathrm{X}$ & o & \\
\hline Navicula veneta & & $\mathrm{O}$ & . & . \\
\hline Nitzschia frustulum & . & $\mathrm{O}$ & o & \\
\hline Sellaphora seminulum & . & $\mathrm{O}$ & o & o \\
\hline Amphora veneta & . & + & & \\
\hline Tryblionella debilis & & o & o & \\
\hline Karayevia oblongella & $\mathrm{o}$ & + & $\mathrm{X}$ & . \\
\hline Achnanthidium cf. minutissimum & . & . & $\mathrm{O}$ & \\
\hline Melosira sp & . & . & $\mathrm{O}$ & \\
\hline Nitzschia $\mathrm{sp} 1$ & & & $\mathrm{O}$ & \\
\hline Planothidium pericavum & & . & + & \\
\hline Diadesmis contenta & & . & + & \\
\hline Diadesmis crozetikerguelensis & & . & + & \\
\hline Diadesmis sp1 & . & o & + & \\
\hline Diadesmis sp2 & . & o & + & + \\
\hline Diadesmis vidalii & & & + & \\
\hline Psammothidium investians & . & & + & \\
\hline Achnanthes coarctata & & & o & \\
\hline Pinnularia subacoricola & & & . & $\mathrm{X}$ \\
\hline Nitzschia palea & & . & & $\mathrm{X}$ \\
\hline Luticola sp1 & & & . & $\mathrm{X}$ \\
\hline Mayamaea permitis & & & . & $\mathrm{O}$ \\
\hline Pinnularia australogibba var. subcapitata & & . & & + \\
\hline Craticula submolesta & . & & & + \\
\hline
\end{tabular}


Table 6. Taxonomical list of all diatom taxa observed in this study. Unidentified species are given provisional letter codes or numbers [Distribution: (C) cosmopolitan, (AMS) Ile Amsterdam, (SA) Subantarctic region, (U) unknown, ((AMS)) Ile Amsterdam but yet undescribed].

Taxon name

Distribution

Achnanthes coarctata (BRÉBISSON) GRUNOW

Achnanthes cf. islandica OESTRUP

Achnanthes muelleri CARLSON

Achnanthes naviformis VAN DE VIJVER et BEYENS

Achnanthidium cf. minutissimum (KÜTZING) CZARNECKI

Amphora sp.

Amphora veneta KüTZING

Caloneis aff. bacillum (Grunow) P.T.Cleve

Chamaepinularia aerophila VAN DE VIJVER et BEYENS

Craticula submolesta (Hustedt) LANGE-BERTALOT

Denticula sundaysensis ARCHIBALD

Diadesmis aff. comperei Le COHU et VAN DE VIJVER

Diadesmis aff. ingeae VAN DE VIJVER

Diadesmis contenta (GRUNOW) D.G.MANN

Diadesmis crozetikerguelensis LE COHU et VAN DE VIJVER

Diadesmis gallica W.SMITH

Diadesmis sp1

Diadesmis sp2

Diadesmis subantarctica LE COHU et VAN DE VIJVER

Diadesmis vidalii VAN DE VIJVER, LedegancK et Beyens

Eunotia cocquytiae VAN DE VIJVER

Eunotia lecohui VAN DE VIJVER

Eunotia muscicola KRASSKE var. muscicola

Eunotia paludosa GRUNOW var. paludosa

Eunotia pugilistica VAN DE VIJVER

Frustulia aff. vulgaris (THWAITES) DE TONI

Frustulia lebouvieri VAN DE VIJVER et GREMMEN

Gomphonema cf. exilissimum GRUNOW

Gomphonema cf. montanum ScHUMANN

Gomphonema parvulum KÜTZING

Hantzschia amphioxys (EHRENBERG) GRUNOW

Hantzschia possessionensis VAN DE VIJVER et BEYENS

Karayevia oblongella (OESTRUP) M.ABOAL

Kobayasiella subantarctica VAN DE VIJVER et VANHOUTTE

Lecohuia $\mathrm{sp}$ 
Table 6 Cont.

\section{Taxon name}

Luticola $\mathrm{sp} 1$

Luticola $\mathrm{sp} 2$

Luticola $\mathrm{sp} 3$

Luticola $\mathrm{sp} 4$

Mayamaea cavernicola VAN DE VIJVER

Mayamaea cf. agrestis (HUSTEDT) LANGE-BERTALOT

Mayamaea permitis (Hustedt) K.BRUder et MEdLIN

Melosira $\mathrm{sp}$

Navicula arvensis HustedT

Navicula cf. tenelloides HustedT

Navicula gregaria DoNKIN

Navicula veneta KÜTZING

Nitzschia acidoclinata LANGE-BERTALOT

Nitzschia cf. liebetruthii RABENHORST

Nitzschia cf. pseudofonticola HUSTEDT

Nitzschia cf. pusilla GRUNOW

Nitzschia communis RABENHORST

Nitzschia commutata GRUNOW

Nitzschia frustulum (KÜTZING) GRUNOw

Nitzschia inconspicua GRUNOw

Nitzschia palea (KützING) W. SMITH

Nitzschia $\mathrm{sp} 1$

Opephora naveana LE COHU

Orthoseira roeseana (RABENHORST) O`MEARA

Orthoseira verleyenii VAN DE VIJVER

Pinnularia acidicola var. acidicola VAN DE VIJVER et LE COHU

Pinnularia amsterdamensis Chattová, VAn de Vijver et Metzeltin

Pinnularia australogibba VAn de Vijver, Chattová et Metzeltin

Pinnularia australogibba var. subcapitata VAn De ViJver, Chattová et Metzeltin

Pinnularia borealis s.l. EHRENBERG

Pinnularia borealis var. subislandica KRAMMER $\quad$ C

Pinnularia bottnica KRAMMER $\quad$ C

Pinnularia cf. obscuriformis KRAMmER U

Pinnularia microstauron (Ehrenberg) CleVe C C

Pinnularia myriamiae VAn de Vijver, Chattová et Metzeltin AMS

Pinnularia perminor Kulikovskiy, Lange-Bertalot et Metzeltin C

Pinnularia pseudohilseana VAN DE VIJVER, ChatTová et MetZeltin AMS

Pinnularia rabenhorstii var. subantarctica VAN DE VIJVER et Le CoHU SA 
Table 6 Cont.

Taxon name

Distribution

Pinnularia robrechtii VAN DE VIJVER

AMS

Pinnularia sinistra KRAMMER

$\mathrm{C}$

Pinnularia sp [cf. divergentissima (GRunow) Cleve]

$\mathrm{U}$

Pinnularia subacoricola Metzeltin, Lange-Bertalot et García-Rodríguez

C

Pinnularia subsinistra Van de Vijver, Chattová et Metzeltin

Pinnularia vixconspicua Chattová, Metzeltin et Van de Vijver

AMS

Pinnularia vlaminghii VAN DE ViJver, Chattová et Metzeltin

Pinnularia whinamiae VAN DE VIJVER

Pinnunavis elegans (W. Sмітн) ОкUNO

Pinnunavis gebhardii (KRASSKe) VAN DE VIJVER

Pinnunavis sp

Placoneis cf. anglica (RALFs) R.LowE

Planothidium delicatulum (Kützing) Round et BukhtiYarova

Planothidium pericavum (CARTER) LANGE-BERTALOT

Planothidium subantarcticum VAN De ViJVER et C.E.Wetzel

Psammothidium abundans (MANGUIN) BUKHTIYAROva et Round

Psammothidium staroneioides (MANGUIN) BUKhtIYARova

Psamnothidium investians (CARTER) BUKHTIYAROva

Pseudostaurosira trainorii E.A.Morales

Rhopalodia rupestris (W. SMITH) KRAMMER

Sellaphora barae VAN DE VIJVER

Sellaphora seminulum (GRUNOw) D.G.MANN

C

Sellaphora $\mathrm{sp} 1$

Stauroforma exiguiformis (LANGE-Bertalot) Flower, Jones et Round

Stauroneis bertrandii VAN DE ViJver et Lange-Bertalot

Stauroneis pseudomuriella VAN DE ViJver et LANGE-BERTALOT

Stauroneis cf. thermicola (J.B.PETERSEN) LUND

Stauroneis kriegeri PATRICK

Tryblionella debilis (ARNOTT) GRUNOW

composed of Sphagnum mosses. Sphagnum is well known for acidifying its environment (CLYMO 1963, 1964; Munson \& GHERINI 1993) and this activity in the isolated Caldera region in combination with the flat geomorphology of the Caldera most likely created the highly acid and oligotrophic habitat where the acid diatom community could develop. Other regions on Ile Amsterdam where Sphagnum could be found (e.g., near the Pignon area), the Sphagnum vegetation is often found on more or less steep slopes where peat formation is less likely.

\section{Conclusion}

The freshwater diatom flora on Ile Amsterdam is unique in many aspects. This study showed the presence of a rather species poor diatom flora although for some genera such as Pinnularia a remarkable high diversity was found. The latter unbalanced diversity is most likely the result of the biogeographical isolation and the oceanic nature of the island. The combination of the subalkaline volcanism that shaped the island and the acidifying properties of Sphagnum most likely resulted 
in the actual composition of these quite contrasting diatom communities that were observed in this study.

\section{ACKNOWLedGements}

The authors wish to thank Dr. J. Whinam for her help during the sampling campaign. Sampling was made possible thanks to the logistic and financial support of the French Polar Institute PaulEmile Victor in the framework of the terrestrial program 136 (Ir. M. Lebouvier \& Dr. Y. Frenot). Part of this research was funded within the FWO project G.0533.07 and Belspo project CCAMBIO. Mrs. M. de Haan is thanked for preparing the samples. Mrs. B. Chattová benefited from an ERASMUS scholarship when studying at the National Botanic Garden of Belgium and the University of Antwerp.

\section{RefERENCES}

Aptroot, A.; Van de Vijver, B.; Lebouvier, M. \& Ertz, D. (2011): Lichens of Ile Amsterdam and Ile Saint Paul (TAAF, southern Indian Ocean). - Nova Hedwigia 92: 343-367.

Bourrelly, P. \& Manguin, E. (1954): Contribution à la flore algale d'eau douce des Iles Kerguelen. - Mémoires de l'Institut des Sciences de Madagascar, Série B 5: $7-58$.

Buckley, T.R.; Attanayake, D. \& Bradler, S. (2009): Extreme convergence in stick insect evolution: Phylogenetic placement of the Lord Howe island tree lobster. - Philosophical Transactions of the Royal Society of London, series B Biological Sciences 276: $1055-1062$.

Cantonati, M.; Van de Vijver, B. \& Lange-Bertalot, H. (2009): Microfissurata gen. nov. (Bacillariophyta), a new diatom genus from dystrophic and intermittently wet terrrestrial habitats. - Journal of Phycology 45: $732-741$.

CHAO, A. (1984): Non-parametric estimation of the number of classes in a population. - Scandinavian Journal of Statistic 11: 265-270.

Chao, A.; Hwang, W.H.; Chen, Y.C. \& Kuo, C.Y. (2000): Estimating the number of shared species in two communities. - Statistica Sinica 10: 227-246.

Clymo, R.S. (1963): Ion exchange in Sphagnum and its relation to bog ecology. - Annals of Botany 27: 309-324.

Clymo, R.S. (1964): The origin of acidity in Sphagnum bogs. - The Bryologist 67: 427-431.

Colwell, R.K. (2009): EstimateS: Statistical estimation of species richness and shared species from samples. Version 8.2.- User's Guide and application published at http://purl.oclcorg/estimates.

Doucet, S. ; Giret, A. ; Weis, D. \& Scontes, J.S. (2003): Géologie des îles Amsterdam et Saint-Paul. Géologues 137: 10-15.

Doucet, S.; Weis, D.; Scoates, J.; Debaille, V. \& Giret, A. (2004): Geochemical and $\mathrm{Hf}-\mathrm{Pb}-\mathrm{Sr}-\mathrm{Nd}$ isotopic constraints on the origin of the Amsterdam-St. Paul (Indian Ocean) hotspot basalts. - Earth and Planetary Science Letters 218: 179-195.

Finlay, B. J. \& Clarke, K. J. (1999): Apparent global ubiquity of species in the protist genus Paraphysomonas. Protist 150: 419-430.

Flatberg, K. I.; Whinam, J. \&. Lebouvier, M. (2011): Three species of Sphagnum endemic to Île Amsterdam, Terres Australes et Antarctiques Françaises: $S$. cavernulosum sp. nov., $S$. complanatum sp. nov. and S. islei. - Journal of Bryology 33: 105-121.

Fleischer, R.C.; James, H.F. \& Olson, S.L. (2008): Convergent evolution of Hawaiian and AustraloPacific honeyeaters from distant songbird ancestors. - Current Biology 18: 1927-1931.

Fránková, M.; Bojková, J.; Poulíč́ová, A.; \& Hájek, M. (2009): The structure and species richness of the diatom assemblages of the Western Carpathian spring fens along the gradient of mineral richness. Fottea 9: 355-368.

Frenot, Y. \& Valleix, T. (1990): Carte des sols de l'Île Amsterdam (TAAF). - Comité National Français pour les Recherches Antarctiques 59: 1-49.

Frenot, Y.; Gloaguen, J.C.; Masse, L. \& Lebouvier, M. (2001): Human activities, ecosystem disturbance and plant invasions in sub-Antarctic Crozet, Kerguelen and Amsterdam Islands. - Biological Conservation 101: 33-50.

Galley, C.; Bytebier, B.; Bellstedt, D.U. \& Linder H.P. (2007): The Cape element in the Afrotemperate flora: from Cape to Cairo? - Proceedings of the Royal Society B 274: 535-543.

GILLESPIE, R.G. (2007): Oceanic islands: models of diversity. - In: Levin S.A. (ed.): Encyclopedia of Biodiversity. - pp. 1-13, Princeton University, New Jersey, U.S.A.

GiRET, A. (1987): Géologie des Terres Australes Françaises. - Comité National Français pour les Recherches Antarctiques 58: 17-41.

Grolle, R. (2002): The Hepaticae and Anthocerotae of the subantarctic and temperate islands in the eastern Southern Hemisphere $\left(90^{\circ} \mathrm{E}\right.$ to $\left.0^{\circ}\right)$ : An annotated catalogue. - Journal of Bryology 24: 57-80.

Heger, T.J.; Mitchell, E.A.D.; Ledeganck, P.; Vincke, S.; Van de ViJver, B. \& Beyens, L. (2009): The curse of taxonomic uncertainty in biogeographical studies of free-living terrestrial protists: a case study of testate amoebae from Amsterdam Island. - Journal of Biogeography 36: 1551-1560.

Hofmann, G.; Werum, M. \& Lange-Bertalot, H. (2011): Diatomeen in Süsswasser-Benthos von Mitteleuropa. - 908 pp., A.R.G.Gantner Verlag K.G., Rugell.

Jones, V.J. (1996): The diversity, distribution and ecology of diatoms from Antarctic inland waters. - Biodiversity and Conservation 5: 1433-1449.

Jongman, R.H.; ter BraAk, C.J.F. \& van TONGeren O.F.R. (1995): Data analysis in community and landscape ecology. - 299 pp., Cambridge University Press, Cambridge.

Kellogg, T. B. \& KellogG, D.E. (2002): Non-Marine and Littoral Diatoms from Antarctic and Sub-Antarctic Locations. Distribution and Updated Taxonomy. Diatom Monographs 1: 1-795.

Kopalová, K. \& Van de Vijver, B. (2013): Structure and ecology of freshwater diatom communities of Byers Peninsula (Livingston Island, South Shetland Islands). - Antarctic Science 25: 239-253.

Kopalová, K.; Nedbalová, L.; NÝvlt, D.; Elster, J. \& Van DE VIJVER, B. (2013): Ecological assessment of the freshwater diatom communities from Ulu Peninsula (James Ross Island, NE Antarctic Peninsula). - Polar Biology 36: 933-948.

Lange-Bertalot, H.; Bąk, M. \& Witkowski, A. (2011): 
Eunotia and some related genera. - Diatoms of Europe 6: 1-747.

Lebouvier, M. \& Frenot, Y. (2007): Conservation and management in the French sub-Antarctic islands and surrounding seas. - Papers and Proceedings of the Royal Society of Tasmania 141: 23-28.

Le Cohu, R. \& Maillard, R. (1983): Les diatomées monoraphidées des Iles Kerguelen. - Annales de Limnologie 19: 143-167.

Le Cohu, R. \& Maillard, R. (1986): Diatomées d'eau douce des Iles Kerguelen (à l'exclusion des Monoraphidées). - Annales de Limnologie 22: 99-118.

LE CoHu, R. (2005): Révision des principales espèces dulçaquicoles d'Achnanthales (Bacillariophyta) des îles subantarctiques de Kerguelen. - Algological Studies 116: 79-114.

Levkov, Z. (2009): Amphora sensu lato. - Diatoms of Europe 5: $1-916$.

Lowe, R.L.; Kociolek, J.P. \& VAN De ViJVer B. (2013): Two new Orthoseira species (Bacillariophyta) from lava tubes. - Phytotaxa 111: 39-52.

Metzeltin, D.; Lange-Bertalot, H. \& Nergui, S. (2009): Diatoms in Mongolia. - Iconographia Diatomologica 20: $1-686$.

Micol, T. \& Jouventin, P. (1995): Restoration of Amsterdam Island, south Indian Ocean, following control of feral cattle. - Biological Conservation 73: 199-206.

Munson, R.K. \& GHERINI, S. (1993): Influence of organic acids on the $\mathrm{pH}$ and acid-neutralizing capacity of Adirondack lakes. - Water Resources Research 29: 891-899.

OpPenheIM, D.R. (1994): Taxonomic studies of Achnanthes (Bacillariophyta) in freshwater maritime Antarctic lakes. - Canadian Journal Botany 72: 1735-1748.

PoulíčKová, A.; Bergová, K.; Hnilica, R. \& Neustupa, J. (2013): Epibryic diatoms from ombrotrophic mires: diversity, gradients and indicating options. - Nova Hedwigia 96: 351-365.

Romero, O.E. \& VAN de ViJver, B. (2011): Cocconeis crozetensis Ehrenberg (Bacillariophyceae): a new monoraphid diatom from subantarctic freshwater and moss habitats. - Diatom Research 26: 89-98.

Rønsted, N.; Chase M.W.; Albach D.C. \& Bello M.A. (2002): Phylogenetic relationships within Plantago (Plantaginaceae): evidence from nuclear ribosomal ITS and plastid trnL-F sequence data. - Botanical Journal of the Linnean Society 139: 323-338.

Sabbe, K.; Verleyen, E.; Hodgson, D.A.; Vanhoutte, K. \& Vyverman, W. (2003): Benthic diatom flora of freshwater and saline lakes in the Larsemann Hills and Rauer Islands (E. Antarctica). - Antarctic Science 15: 227-248.

SChMidt, R.; Mäusbacher, R. \& MÜller, J. (1990): Holocene diatom flora and stratigraphy from sediment cores of two Antarctic lakes (King George Island). - Journal of Paleolimnology 3: 55-74.

Souffreau, C.; Vanormelingen, P.; Van de Vijver, B.; IsheVa, T.; Verleyen, E.; Sabbe K. \& Vyverman W. (2013): Molecular evidence for distinct Antarctic lineages in the cosmopolitan terrestrial diatoms Pinnularia borealis and Hantzschia amphioxys. Protist 164: 101 -115 .

Sørensen, T. (1948): A method of establishing groups of equal amplitude in plant sociology based on similarity of species content. - Det Kongelige
Danske Videnskabernes Selskabs Skrifter 54: 1-34. Stevenson, A.C.; Juggins, S.; Birks, H.J.B.; Anderson, D.S.; Anderson, N.J.; Battarbee, R.W.; Berge, F.; Davis, R.B.; Flower, R.J.; Haworth, E.Y.; Jones, V.J.; Kingston, J.C.; Kreiser, A.M.; Line, J.M.; Munro, M.A.R. \& RENBerG, I. (1991): The surface water acidification project paleolimnology programme: modern diatom/lake water chemistry data-set. -86 pp., Ensis, London.

Stonehouse, B. (1982): La zonation écologique sous les hautes latitudes australes. - Comité National Français pour les Recherches Antarctiques 51: 531-537.

ter BraAk, C.J.F. \& Prentice, I.C. (1988): A theory of gradient analysis. - Advances in Ecological Research 18: 271-7.

Ter BraAk, C.J.F. \& Šmilauer, P. (2002): CANOCO reference manual and CanoDraw for Windows user's guide. Software for Canonical Community Ordination (version 4.5). Biometris, Wageningen \& České Budějovice.

Theriot, E. C.; Fritz, S.C.; Whitlock, C. \& Conley, D. J. (2006): Late Quaternary rapid morphological evolution of an endemic diatom in Yellowstone Lake, Wyoming. - Paleobiology 32: 38-54.

Tréhen, P.; Frenot, Y.; Lebouvier, M. \& Vernon, P. (1990): Invertebrate fauna and their role in the degradation of cattle dung at Amsterdam Island. - In: KERRY, K.R. \& Hempel, G. (eds): Antarctic ecosystems ecological change and conservation. - pp. 37-46, Springer, Berlin - Heidelberg.

VÁŇa, J.; Lebouvier, M.; Ochyra, R.; Bednarek-Ochyra, H. \& Cykowska, B. (2010): Two noteworthy records of hepatics from Île Amsterdam in the South Indian Ocean. - Nova Hedwigia 138: 231

VAn DE ViJver, B. \& Beyens, L (1999a): Biogeography and ecology of freshwater diatoms in sub-Antarctica: a review. - Journal of Biogeography 26: 993-1000.

Van de ViJver, B. \& Beyens, L (1999b): Moss diatom communities from Ile de la Possession (Crozet, subAntarctica) and their relationship with moisture. Polar Biology 22: 232-240.

VAn de Vijver, B. \& Beyens, L. (1999c): Première contribution à la flore diatomique de l'Île Amsterdam (Terres Australes et Antarctiques Françaises). Annales de Limnologie 35: 85-94.

Van de Vijver, B.; Ledeganck, P. \& Beyens, L. (2001): Habitat preference in freshwater diatom communities from sub-Antarctic Îles Kerguelen. - Antarctic Science 13: 28-36.

VAn de Vijver, B.; Frenot, Y. \& Beyens, L. (2002a): Freshwater diatoms from Île de la Possession (Crozet archipelago, Subantarctica). - Bibliotheca Diatomologica 46: 1-412.

Van de Vijver, B.; Ledeganc, P. \& Lebouvier, M. (2002b) Luticola beyensii, a new aerophilous diatom from Ile Saint Paul (TAAF, Indian Ocean). - Diatom Research 17: 235-241.

VAn de ViJver, B.; Beyens, L.;Vincke, S. \& Gremmen, N.J.M. (2004a): Moss-inhabiting diatom communities from Heard Island, sub-Antarctic. - Polar Biology, 27: 532-543.

Van de Vijver, B.; Beyens, L. \& Lange-Bertalot, H. (2004b): The genus Stauroneis in the Arctic and (Sub) Antarctic Regions. - Bibliotheca Diatomologica 51: $1-311$. 
Van de Vijver, B.; Gremmen, N. \& Beyens L. (2005): The genus Stauroneis (Bacillariophyceae) in the Antarctic Region. - Journal of Biogeography 32: 1791-1798.

Van de ViJver, B.; Gremmen, N. \& Smith, V. (2008a): Diatom communities from the sub-Antarctic Prince Edward Islands: diversity and distribution patterns. - Polar Biology 31: 795-808.

Van de Vijver, B.; Beyens, L. \& Lebouvier, M. (2008b): The genus Eunotia on the volcanic island, Île Amsterdam (southern Indian Ocean). - Nova Hedwigia 87: 113128.

VAN de ViJver, B. \& Zidarova, R. (2011): Five new taxa in the genus Pinnularia sectio Distantes (Bacillariophyta) from Livingston Island (South Shetland Islands). Phytotaxa 24: 39-50.

Van de Vijver, B.; Chattová, B.; Metzeltin, D. \& Lebouvier, M. (2012): The genus Pinnularia (Bacillariophyta) on Ile Amsterdam (TAAF, southern Indian Ocean). Nova Hedwigia Beiheifte 141: 201-236.

VAn de ViJver, B. \& Cox, E.J. (2013): New and interesting small-celled naviculoid diatoms (Bacillariophyceae) from a lava tube cave on Ile Amsterdam (TAAF, southern Indian Ocean). - Cryptogamie, Algologie 34: $37-47$.
VAN DER WerfF, A. (1955): A new method for cleaning and concentrating diatoms and other organisms. Verhandlungen der Internationalen Vereinigung für theoretische und angewandte Limnologie 12: 276277

Vyverman, W.; Verleyen, E.; Sabbe, K.; Vanhoutte, K.; Sterken, M.; Hodgson, D. A.; Mann D.G.; Juggins, S.; VAn de ViJVer, B.; Jones, V.; Flower, R.; Roberts, D.; Chepurnov, V.A.; Kilroy, C.;Vanormelingen, P. \& Wever, A. D. (2007): Historical processes constrain patterns in global diatom diversity. Ecology 88: 1924-1931.

Witkowski, A.; Kulikovskyi, M. \& RiauX-Gobin, C. (2012): Achnanthidium sieminskae, a new diatom species from the Kerguelen Archipelago (Austral Islands). - In: Wolowski, K.; Kaczmarska, I.; Ehrman, J.M. \& Wojtal A.Z. (eds): Current Advances in algal taxonomy and its implications: phylogenetic, ecological and applied perspective. - pp. 61-68, W. Szafer Institute of Botany, Polish Academy of Sciences, Kraków.

(C) Czech Phycological Society (2014)

Received December 5, 2013

Accepted January 13, 2014 